\title{
Michał PIENIAS
}

Łódź

\section{Znaczenie tożsamości wizerunkowej partii i jej kandydatów w trakcie kampanii wyborczej}

\begin{abstract}
Streszczenie: Współczesna polityka coraz większą uwagę przywiązuje do tożsamości wizerunkowej, jednocześnie zmniejszając rangę tożsamości ideologicznej. Dla partii i polityków ważniejszą od ciagłości tożsamości ideologicznej staje się elastyczność, zarówno w aspekcie wizerunkowym, jak i ideologicznym. Politycy unikają często podejmowania decyzji niepopularnych społecznie w obawie przed utratą poparcia, kreując jednocześnie swój wizerunek zgodnie z oczekiwaniami wyborców. Gloryfikowanie tożsamości wizerunkowej staje się tym samym celem samym w sobie, oderwanym często od tożsamości ideologicznej. Moim zdaniem te dwa rodzaje tożsamości wcale się nie wykluczają, jednak w dobie dominacji mediów szukających sensacji i społeczeństwa, które w znikomym stopniu interesuje się merytoryczną debatą w polityce, rządzący wybierają ten rodzaj tożsamości, który bardziej zaspokaja potrzeby środków masowego przekazu oraz ich odbiorców. Wzrost znaczenia wizerunku związany jest z bardziej ogólnymi zmianami społeczno-politycznymi, zwłaszcza z malejącą lojalnością partyjną zmianą modelu partii politycznej (partia wyborcza ewoluuje w kierunku partii rynkowej), oraz ze zdominowaniem sfery publicznej przez media elektroniczne.
\end{abstract}

Słowa kluczowe: tożsamość wizerunkowa, marketing polityczny, partia polityczna, wizerunek polityka, tożsamość ideologiczna

\section{Wstęp}

$\mathbf{W}$ spółczesna polityka współpracując z mediami próbuje dostosować się do ich oczekiwań, korzysta tym samym z rad ekspertów od marketingu politycznego. Na wzrost znaczenia tożsamości wizerunkowej zarówno w Polsce, jak i w wielu krajach europejskich wpłynęło kilka czynników; po pierwsze, obserwowalny spadek znaczenia tożsamości ideologicznej partii politycznych; po drugie, rosnąca rola w partiach młodych polityków - pragmatyków, pragnących pełnić funkcję menedżerów i przeszczepiać na grunt polityki mechanizmy zaczerpnięte z zarządzania i marketingu; po trzecie wzrost pozycji mediów, które zaczęły współtworzyć świat polityki m.in. poprzez wpływanie na przebieg kampanii wyborczych; po czwarte w wielu krajach europejskich można zaobserwować spadek uczestnictwa obywateli w wyborach zarówno krajowych, jak i do Parlamentu Europejskiego.

Pisząc o tożsamości wizerunkowej w przebiegu kampanii wyborczej, rozumiem ją jako kształtowanie obrazu partii i polityka za pomocą narzędzi marketingowych, których celem jest tworzenie kompleksowego wizerunku, w skład którego wchodzi spójna komunikacja werbalna i niewerbalna polityka, a w przypadku jego partii rozbudowana symbolika (m.in. logo, szata graficzna oraz wykorzystywana kolorystyka). Ważną rolę w kształtowaniu tożsamości wizerunkowej pełni również rodowód partii, ciagłość jej istnienia, a w przypadku polityka jego merytoryczne przygotowanie. Moim zdaniem tożsa- 
mość wizerunkowa staje się coraz ważniejsza we współczesnej polityce, spychając tożsamość ideologiczną ${ }^{1}$ na dalszy plan. Dla partii i polityków ważniejsze od ciąłości (pewnego kontinuum) staje się elastyczność, zarówno w aspekcie wizerunkowym, jak i ideologicznym. Politycy unikają często podejmowania decyzji niepopularnych społecznie w obawie przed utratą poparcia, kreując jednocześnie swój wizerunek zgodnie z oczekiwaniami wyborców. Gloryfikowanie tożsamości wizerunkowej staje się tym samym celem samym w sobie, oderwanym często od tożsamości ideologicznej. Moim zdaniem opisywane dwa rodzaje tożsamości wcale się nie wykluczaja, jednak w dobie mediów szukających sensacji i społeczeństwa, które w znikomym stopniu interesuje się merytoryczną debatą w polityce, rządzący wybierają ten rodzaj tożsamości, który bardziej zaspokaja potrzeby środków masowego przekazu oraz ich odbiorców. M. Karwat określa współczesną tożsamość mianem tożsamości blankietowej, przyrównując ją do gotowego formularza, w którym znajdują się puste miejsca, gotowe tylko do wypełnienia według podanego schematu (Karwat, 2008, s. 165).

Upadek komunizmu w 1989 roku zapoczątkował w Polsce serię zmian związanych z rozwojem demokracji; doprowadził do wolności słowa, przyczynił się do rozwoju gospodarki wolnorynkowej. Politycy, starając się uzyskać przychylność opinii publicznej i środków masowego przekazu, zaczęli dostosowywać się do reguł panujących w marketingu i public relations. Rządzący zrozumieli, iż w demokracji wyborcy nie tylko zwracają uwagę na słowa wypowiadane przez elity polityczne, ale także na ich komunikację niewerbalna.

\section{Znaczenie wizerunku dla polityków i ich partii politycznych ${ }^{2}$}

Politycy, dbając o swój pozytywny wizerunek, czynią to zwłaszcza przed wyborami parlamentarnymi. Obawiają się jego utraty za sprawą nieprzychylnych mediów, ataków ze strony internautów, rozpisujących się na forach czy blogach.

Według P. Pawełczyka wyborcy podejmują decyzję o poparciu konkretnego kandydata głównie pod wpływem kreowanego wizerunku politycznego, a nie na podstawie wiedzy merytorycznej kandydującej osoby. W demokracji masowej najistotniejsze jest, aby produkt polityczny znajdował swego nabywcę, natomiast racjonalność dokonywania wyboru jest sprawą wtórną (Pawełczyk, 2005, s. 95).

Z kolei zdaniem J. Reykowskiego jednym z ważniejszych elementów orientacji obywateli w świecie polityki jest diagnoza i ocena politycznych postaci - przywódców, działaczy, funkcjonariuszy publicznych itp. Ocena taka jest przesłanką dokonywanych

${ }^{1}$ Tożsamość ideologiczną rozumiem jako zbiór wartości i norm, z którymi identyfikują się zarówno członkowie partii politycznej oraz jej agend (stowarzyszeń czy organizacji młodzieżowych), jak również osoby należące do elektoratu wyborczego.

${ }^{2}$ Partia polityczna rozumiana jest tutaj jako organizacja świadcząca trzy rodzaje usług: 1) pomaga osobom kandydującym do władzy ustawodawczej w wygraniu wyborów, 2) pomaga ustawodawcom w uchwaleniu ustaw oraz 3) pomaga członkom zbiorowości w wywieraniu wpływu na ustanawiane prawa (J. P. Gunning, Zrozumieć demokrację. Wprowadzenie do teorii wyboru publicznego, Warszawa 2001, s. 247). 
wyborów lub innych działań popierających lub zwalczających danego polityka. Oceny formułowane są na podstawie trzech wiodących przesłań:

1) informacji o politycznej działalności (na przykład o sposobie głosowania w parlamencie). Rzadko kto może systematycznie śledzić działania danego polityka. Większość zadowala się kilkoma najlepiej zapamiętanymi obserwacjami. Często są to informacje mające znaczenie afektywne. Na tej podstawie wytwarza się ogólne nastawienie wobec kandydata (sympatia-antypatia);

2) informacji o cechach osobistych polityka - o jego wyglądzie, charakterze, wykształceniu, pochodzeniu itp. Dla wielu ludzi charakter polityka ma duże znaczenie, trudno jednak zdobyć wiarygodne informacje na ten temat. Dlatego często korzysta się z informacji pośrednich. Jedną z takich informacji jest wygląd fizyczny. Pozwala on domyślać się wielu różnych cech polityka;

3) informacji o przynależności do partii lub do obozów politycznych. Jeśli informacje o dokonaniach polityka bądź o jego cechach są niedostępne czy niejednoznaczne lub sprzeczne, ludzie wybierają łatwiejszą strategię, biorąc pod uwagę przynależność partyjną kandydata. Strategię tę stosują wtedy, gdy dysponują znaczną wiedzą o ugrupowaniu politycznym i mają do niego określony stosunek, natomiast nie znają osób przez to ugrupowanie wybranych (Reykowski, 2005, s. 383-384).

Niektórzy dziennikarze, jak również część ekspertów od marketingu politycznego przekonują obywateli, iż za zwycięstwo bądź porażkę odpowiada nie tyle program wyborczy a ugruntowany w świadomości opinii publicznej wizerunek danego polityka. Czym właściwie jest to pojęcie?

Teoria marketingu politycznego proponuje traktowanie wizerunku jako:

- po pierwsze - produktu politycznego - czyli tego zasobu, który oferowany jest nabywcom politycznym przez oferentów na rynku politycznym;

— po drugie - jako zasobu politycznego, czyli tego, co znajduje się w dyspozycji grupy lub samego lidera politycznego i może przekształcić się w kapitał wówczas, gdy na rynku istnieje na niego popyt;

- po trzecie - jako kapitału, czyli zasobów odpowiednio uruchomionych na rynku i przynoszących zysk (Cichosz, 2004, s. 81).

O wizerunku polityka decydują zarówno cechy jego wyglądu zewnętrznego, jak i cechy jego osobowości, a także - czynniki, które ukształtowały osobowość lidera - miejsce jego pochodzenia, rodzina, zawód i wykształcenie. Na wizerunek wpływa również otoczenie polityka, grono jego najbliższych doradców oraz sposób organizacji przestrzeni wokół niego (ibidem, s. 82).

Według W. Cwaliny i A. Falkowskiego wizerunek (image) polityka oznacza ,[...] tworzone w określonym celu (np. wyborczym) szczególnego rodzaju wyobrażenie, które poprzez wywołanie skojarzeń przydaje obiektowi dodatkowych wartości (np. społeczno-psychologicznych, etycznych czy osobowościowych) i w ten sposób przyczynia się do jego emocjonalnego odbioru" (Cwalina, Falkowski, 2006, s. 153).

W opinii tych badaczy na wizerunek polityka wpływająjego zachowanie, prezentacja jego osoby w mediach oraz na folderach reklamowych, komunikacja niewerbalna, cechy osobowe (płeć czy wzrost), jak również odpowiedni ubiór (ibidem, s. 154).

Celem wizerunku polityka jest wywołanie u wyborców pozytywnego wyobrażenia kandydata i zbudowanie w środkach masowego przekazu obrazu polityka, który w naj- 
pełniejszy sposób odpowiadałby oczekiwaniom elektoratu (Falkowski, Michalak, 2009, s. 252).

M. Jeziński wyróżnia następujące typy wizerunków politycznych: eksperta, ojca, amanta, herosa, zwykłego człowieka, szaraka, ekscentryka, idola, błazna oraz luzaka.

Typy wizerunków politycznych

\begin{tabular}{|l|l|l||}
\hline \multirow{2}{*}{$\begin{array}{c}\text { Typ } \\
\text { wizerunku }\end{array}$} & \multicolumn{2}{|c|}{ Podstawowe cechy - typy } \\
\cline { 2 - 4 } Ekspert & $\begin{array}{l}|c| \\
\text { rzeczowość, szeroka wiedza, kompetencje, } \\
\text { odpowiedzialność, skuteczność }\end{array}$ & $\begin{array}{l}\text { skrupulatność, dokładność, umiar, wiarygod- } \\
\text { ność, rzetelność }\end{array}$ \\
\hline Ojciec & $\begin{array}{l}\text { paternalizm, protekcjonalizm, odpowiedzial- } \\
\text { ność, mądrość polityczna }\end{array}$ & opiekuńczość, odwaga, opanowanie, mądrość \\
\hline Amant & $\begin{array}{l}\text { atrakcyjna powierzchowność, skuteczność, dy- } \\
\text { namizm, zdecydowanie }\end{array}$ & $\begin{array}{l}\text { atrakcyjna powierzchowność, dynamizm, nar- } \\
\text { cyzm, świeżość, romantyzm, sentymentalizm }\end{array}$ \\
\hline Heros & $\begin{array}{l}\text { charyzma, zdecydowanie, autorytarne metody } \\
\text { podejmowania decyzji, profetyczna wizja ładu } \\
\text { politycznego, poczucie misji }\end{array}$ & $\begin{array}{l}\text { charyzma, odwaga, zdecydowanie, pasja w dzia- } \\
\text { łaniu }\end{array}$ \\
\hline $\begin{array}{l}\text { Zwykły } \\
\text { człowiek }\end{array}$ & $\begin{array}{l}\text { skrócenie dystansu między politykiem a wy- } \\
\text { borca, wiarygodność }\end{array}$ & $\begin{array}{l}\text { nawiązywanie do wspólnoty pochodzenia, } \\
\text { podkreślanie swojskości, umiar }\end{array}$ \\
\hline Szarak & bierność, uległość & przeciętność, apatia, uległość \\
\hline Ekscentryk & $\begin{array}{l}\text { pasja, nietypowe podejście do polityki, nieco- } \\
\text { dzienne zachowania na arenie politycznej }\end{array}$ & $\begin{array}{l}\text { nietypowe podejście do rzeczywistości spo- } \\
\text { łecznej, niestandardowe zachowania w życiu } \\
\text { codziennym }\end{array}$ \\
\hline Idol & $\begin{array}{l}\text { zdecydowanie, charyzma, skuteczność, umie- } \\
\text { jętność podejmowania decyzji }\end{array}$ & $\begin{array}{l}\text { niedostępność, zdecydowanie, charyzma, kon- } \\
\text { sekwencja }\end{array}$ \\
\hline Błazen & $\begin{array}{l}\text { nieodpowiedzialność polityczna, niezamie- } \\
\text { rzona śmieszność wywołana zachowaniem na } \\
\text { scenie politycznej }\end{array}$ & $\begin{array}{l}\text { nieodpowiedzialność, niezamierzona śmiesz- } \\
\text { ność w życiu codziennym }\end{array}$ \\
\hline Luzak & $\begin{array}{l}\text { skuteczność, ironiczny stosunek do rzeczywi- } \\
\text { stości politycznej, poczucie humoru }\end{array}$ & $\begin{array}{l}\text { ironiczny stosunek do rzeczywistości społecz- } \\
\text { nej, poczucie humoru }\end{array}$ \\
\hline
\end{tabular}

Źródło: M. Jeziński, Wizerunek polityczny jako element strategii wyborczej, w: Kampania wyborcza: marketingowe aspekty komunikowania politycznego, red. B. Dobek-Ostrowska, Wydawnictwo Uniwersytetu Wrocławskiego, Wrocław 2005, s. 124-129.

Politycy mogą odpowiadać kilku powyższym typom wizerunku zgodnie ze społecznym zapotrzebowaniem ma określoną osobowość polityczną. Według M. Mazura kształtowany wizerunek przygotowywany zwłaszcza w kampaniach wyborczych może opierać się zarówno na aspektach personalnych kandydata lub partii oraz na zagadnieniach merytorycznych. Według badacza wymiar merytoryczny nie wyklucza aspektów wizerunkowych, jak to ma miejsce w spopularyzowanych w badaniach komunikowania politycznego klasyfikacjach przekazów politycznych, uwzględniających podział na treści wizerunkowe i programowe (Mazur, 2009, s. 84-85).

Wzrost znaczenia wizerunku związany jest zmianami społeczno-politycznymi w środowisku kampanii wyborczej, zwłaszcza z malejącą lojalnością partyjną, zmianą modelu partii politycznej (partia wyborcza ewoluuje w kierunku partii rynkowej), oraz zdomino- 
waniu sfery publicznej przez media elektroniczne (ibidem, s. 85). Jak podkreśla J. Habermas we współczesnym społeczeństwie politycy dbają o swój wizerunek nie tylko, żeby dostosować się do oczekiwań rynku wyborczego, ale przede wszystkim pragną za pomocą wskaźników popularności kontrolować opinie i nastroje społeczne (Habermas, 2007, s. 393).

Zdaniem H. Przybylskiego wizerunek polityka prezentowany w ramach działań public relations składa się z dwóch elementów. Z jednej strony image musi odpowiadać zwolennikom ugrupowania wysuwającego kandydata na stanowisko, $\mathrm{z}$ drugiej strony - szerokiej publiczności, która decydować będzie o wyborze, a po nim podporządkuje się zwycięzcom.

W związku z tym najbardziej efektywny image musi być złożony z następujących elementów:

- dążenia do urzeczywistnienia dobra wspólnego;

— stanowiska w sprawie sprawiedliwych kryteriów dystrybucji dóbr;

— budzenia potrzeby bezpieczeństwa, umiejętności organizacyjnych.

Poza tym ważne są ze względu na rolę mediów, spotkań wyborczych i możliwości publicznego oddziaływania:

- fotogeniczność;

— odpowiadający większości sposób zachowania i obycia w pracy z mediami;

— wzorowe życie rodzinne;

— spolegliwość w stosunkach ze współpracownikami i w szerszej grupie;

- sprawne posługiwanie się narzędziami komunikacji społecznej (retoryka, znajomość języków obcych itp.) (Przybylski, 2004, s. 256).

Według M. Karwata, wielu polityków skoncentrowało się przede wszystkim na swoim wizerunku zapominając, że to w cale nie on decyduje o ich profesjonalizmie. Politycy, pragnący zyskać społeczne uznanie powinni pomyśleć w pierwszej kolejności o tożsamości, a później skupić się na wizerunku (Karwat, 2009, s. 237). Jak podkreśla M. Karwat, politycy kierują się często autonegacją polegającą na porzuceniu dotychczasowej tożsamości czy ideałów i ucieczką do nowotworzonych partii, pozbawionych ciagłości i wspólnych wartości. Politycy budują własną wiarygodność na cudzych porażkach i krytyce tych osób (ibidem, s. 239).

Jak podkreśla H. Przybylski, wizerunek oraz działania z zakresu marketingu politycznego muszą być powiązane z tożsamością danego ugrupowania politycznego, nie można kreować wizerunku odcinając się od tożsamości (Przybylski, 2004, s. 255).

Na wizerunek polityka wpływa również jego moralność. G. Matuszak przedstawia dekalog moralny polityka, którego celem jest z jednej strony określenie standardów działalności politycznej ludzi, z drugiej umożliwienie oceny rządzących według kryteriów, które powinny zaistnieć w świadomości obywateli:

1) głównym celem i miarą postępowania polityka ma być człowiek: jednostka i społeczeństwo, ich dobro i pomyślność, a nie abstrakcyjne mechanizmy, procesy i wskaźniki, np. inflacji, stóp oprocentowania, wysokości PKB itp.;

2) polityk powinien dostrzegać ludzi i świat, na którym oni żyją w całej różnorodności i wielobarwności, a nie tylko w kategoriach bieli i czerni oraz dychotomicznego rozróżnienia - oni i my;

3) polityk powinien mieć poczucie służby społecznej, to on jest dla ludzi, a nie odwrotnie; 
4) politykowi powinna być obca prywata osobista i grupowa;

5) nie wolno traktować ludzi i ich spraw instrumentalnie, należy być człowiekiem honoru odpowiedzialnym za swoje słowa i czyny;

6) polityk musi szukać dróg porozumienia i kompromisu;

7) w polityce należy wyzbyć się osobistych urazów i niechęci;

8) należy bezustannie podnosić swoją wiedzę, zwłaszcza w dziedzinie politycznej aktywności;

9) polityka powinna cechować pracowitość i sumienność w wypełnianiu swoich obowiązków;

10) osoby będące politykami nie mogą zapominać o osobistej przyzwoitości (Matuszak, 2010, s. 176-177).

Jak widać skuteczne zarządzanie wizerunkiem powinno być działaniem świadomym, opartym na umiejętnej komunikacji z mediami. Na image polityka wpływa także przygotowanie merytoryczne takiej osoby i kierowanie się przez nią zasadami moralnymi.

Druga połowa XX wieku związana jest m.in. z szybkim rozwojem marketingu politycznego, który służy zarówno politykom, jak i ich ugrupowaniom partyjnym. W literaturze przedmiotu można spotkać wiele definicji marketingu politycznego, jak i marketingu wyborczego.

Zdaniem M. Jezińskiego, marketing polityczny ma na celu przekonanie obywateli, że charyzmatyczni przywódcy powinni nimi rządzić w oparciu o program polityczny odwołujący się do ideologii danego ugrupowania (Jeziński, 2007, s. 84). G. Ulicka uważa, że marketing polityczny jest wykorzystywany przy tworzeniu projektów i programów politycznych, ich promocji oraz przy zastosowaniu środków komunikacji (badania opinii publicznej, media, w tym zwłaszcza telewizja i internet, reklama, public relations). Według tej badaczki na kształt polityki ma wpływ oprócz aspektów marketingowych także kultura polityczna elit i społeczeństwa, decydująca o standardach etycznych w państwie i granicach aprobaty bądź dezaprobaty społecznej dla zachowań polityków (Ulicka, 2010, s. 12-13). J. Sztumski uważa, że marketing polityczny stał się sposobem komunikowania się elit władzy z obywatelami, w tym wyrzuconymi przez ,niewidzialną rękę rynku" na margines społeczny - w swoim myśleniu, opiniach i postawach wobec problemów społeczno-politycznych, których trzeba zainteresować, przekonać, pozyskać i skłonić do określonych zachowań pożądanych dla sprawujących władzę albo też dążących do władzy (Sztumski, 2002, s. 19).

Rozwój marketingu doprowadził do uznania części polityków, że program nie jest już istotny, najważniejszy jest natomiast wizerunek zaspokajający gusta odbiorców. Według M. Karwata, fetyszyzacja marketingu opiera się na uznaniu trzech rzekomych oczywistości.

Po pierwsze, uznano, że atrakcyjny wizerunek może zastappić wyraźne i rzetelne samookreślenie. W celu odniesienia sukcesu wystarczy posłuchać rad odpowiedniego fachowca, który powie wyborcom - konsumentom, o kogo chodzi, kierując się niczym innym, jak tylko aktualnym popytem, koniunkturą, ewentualnie odkryciem jakiejś niszy dla siebie.

Drugie założenie: wizerunek może być nawet banalny, nijaki, kiczowaty, bo też nie chodzi o żadną wyrazistość ani oryginalność, lecz o dostosowanie podaży do popytu. Oferta ,programowa” ma być taka, jak ,zamówienie społeczne” wyrosłe ze stereotypów, złudzeń, chwilowych nastrojów. 
I trzecie przekonanie, ściśle związane z poprzednim: sukces polityczny zależy jakoby nie od dokonań i ocen społecznych, nie od tego, co pozostawiamy po sobie, lecz od handlowego sprytu, aby przeterminowany towar przedstawić w nowym opakowaniu. Przyglądając się takiej ofercie, zauważamy, że poszukiwania dotyczą tylko innego logo, na zasadzie zniszczenia konkurencji (Karwat, 2009, s. 235-236).

Jak podkreśla R. Wiszniowski, rynkowa orientacja zachowań polityków i ich partii jest czymś zupełnie naturalnym. Wpływ na to mają cztery czynniki - po pierwsze, załamanie się systemu komunistycznego, w którym nie istniała zasada nieskrępowanej rywalizacji politycznej. Po drugie, globalny dostęp do informacji emitowanych poprzez środki masowego przekazu - kandydaci i partie polityczne zmuszone są do apelowania w sposób bardziej wyrazisty i bezpośredni do wszystkich zidentyfikowanych grup wyborców. Po trzecie, wdrażanie technologii telekomunikacyjnych i informatycznych, które umożliwiają prezentowanie zjawisk politycznych. Po czwarte, racjonalizacja zachowań wyborczych, co oznacza m.in., że obywatele (wyborcy) są coraz bardziej nieufni w stosunku do partii i kandydatów politycznych - w sposób przemyślany głosują na tych kandydatów i te partie, które ich zdaniem mają najciekawszą ofertę wyborczą, nie polegając już jedynie na opiniach liderów partii bądź innych instytucji bezpośrednio zaangażowanych w życie polityczne (Wiszniowski, 2002, s. 45).

F. Bylok podkreśla, że w społeczeństwie konsumpcyjnym sfera polityki funkcjonuje na podobieństwo sfery konsumpcji. W polityce podobnie jak na rynku konsumenckim polityk tworzy produkt, którym jest jego wizerunek i program polityczny i zachęca wyborców do nabycia tego produktu tj. zagłosowania na niego w najbliższych wyborach. W celu zachęcenia potencjalnego wyborcy polityk stosuje różne socjotechniki. Często dochodzi do manipulowania wyborcami poprzez stawianie obietnic wyborczych, które często nie są realizowane (Bylok, 2011, s. 75-76).

Celem kampanii wyborczych jest wygranie wyborów. Zaczerpnięte z terminologii wojskowej pojęcie kampanii podkreśla jej funkcjonalny charakter i w wyborczym kontekście oznacza wszelkie wysiłki podmiotu politycznego zmierzające do maksymalizacji poparcia wyborczego (Mazur, 2009, s. 81). Obecnie w prace nad kampanią wyborczą angażuje się specjalistów w zakresie komunikowania społecznego, politycznego, komunikowania masowego, charakteryzatorów, trenerów szkolących umiejętności mówienia i publicznych wystąień, politologów, specjalistów do spraw mediów (Łaska-Formejster, 2002, s. 58-59).

Jak podkreśla M. Karwat współczesne kampanie wyborcze nie kończą się z dniem ogłoszenia wyników wyborów. Prawie cały okres rządów oraz walki opozycji z rządami staje się permanentną kampanią wyborczą. Przy tym media obsługują nie tyle proces rzetelnej akredytacji (prezentacji i weryfikacji społecznej programów, zasobów, potencjału intelektualnego i kadrowego, osiagnięć i zasług pretendentów), ile proces akredytacji zmistyfikowanej (kreacja wizerunku odpowiadającego oczekiwaniom odbiorców, choć niekoniecznie rzeczywistym cechom kandydatów) oraz złośliwej dyskredytacji za pomocą dygresji, aktów dywersji, zniewag, szykan, zniesławiania donosami, oszczerstw, obmowy, intryg. Przerost mody na przecieki i dziennikarstwo śledcze powoduje z kolei zatarcie granicy między informowaniem a czarnym PR (Karwat, 2009, s. 56-57).

Sidney Blumentahl stworzył pojęcie „kampanii permanentnej”, jako „kombinacji działań służących tworzeniu wizerunku oraz strategicznej kalkulacji, które zmienia pro- 
ces rządzenia w nieustanną kampanię i przekształca rząd w instrument przeznaczony do utrzymania popularności rządzących” (Blumentahl, 1982, za: Garlicki, s. 33-34).

J. Garlicki wyróżnił czynniki, które determinują powstanie i działanie mechanizmów kampanii permanentnej: 1) rosnąca rola mediów, a zwłaszcza telewizji w komunikowaniu, a czasem wręcz kreowaniu polityki; 2) rozwój nowych mediów, a szczególnie Internetu; 3) wzrost roli i wpływu opinii publicznej na politykę, której diagnozy dostarczają sondaże opinii i badania marketingowe; 4) powstanie modelu polityki plebiscytarnej, określanej inaczej polityką sondażową, czyli działania ośrodka decyzyjnego pod wpływem wyników badania opinii. Ośrodek decyzyjny może natomiast wykorzystywać działania PR w celu wpływania na nastroje społeczne; 5) funkcjonowanie płaszczyzny nieustannego sporu między rządzącymi a ugrupowaniami opozycyjnymi, a zwłaszcza ich liderami; 6) narastająca częstotliwość wyborów, a w szczególności rozdzielenie wyborów parlamentarnych, prezydenckich i samorządowych, co przyczynia się do wytwarzania atmosfery ciagłej kampanii wyborczej i stosowania bez przerwy technik kampanijnych; 7) profesjonalizacja kampanii oraz wzrost roli konsultantów politycznych w różnych stadiach komunikowania politycznego, co wpływa także na redukcję roli aparatów partyjnych; 8) działania sztabów zmierzające do segmentacji wyborców i identyfikacji grup docelowych, do których przede wszystkim adresowana będzie kampania komunikacyjna (Garlicki, 2010, s. 34-35).

Ważną rolę w budowaniu strategii wyborczych odgrywają spin doktorzy oraz media spinning. „Mianem «media spinning» określa się pogardliwie sposób uprawiania polityki informacyjnej opartej na działaniu za kulisami, manipulowaniu faktami i ludźmi mediów, reglamentowaniu informacji, podsuwaniu dziennikarzom do interpretowania i skomentowania różnych dokumentów, negatywnej propagandzie w mediach opartej najczęściej na zmyślonych lub niesprawdzalnych, ale prawdopodobnych zdarzeniach" (Olędzki, 2006, s. 30).

$\mathrm{Z}$ pojęciem media spinning wiąże się określenie spin doctoringu, które nabrało wydźwięku pejoratywnego za sprawą negatywnych doniesień medialnych o tym zjawisku. „Słowo spin oznacza w języku angielskim «snuć», «układać», «komponować». Zatem spin doctor «leczy niedobre historie» i tworzy «lepsze», zaś spinning to nie krótka wędka, lecz manipulacja faktami, reglamentowanie informacji, podsuwanie interpretacji faktów, kontrolowane przecieki, wykorzystywanie «układów» w mediach itp." (Przybylski, 2004, s. 271). W. Jabłoński próbuje pokazać, iż spin doctoring nie musi oznaczać manipulowania mediami, zagrażać demokracji, czy też negatywnie oddziaływać na społeczeństwo. Spin doctoring polega na świadomym nakręcaniu informacji na użytek mediów i jako zaplanowana działalność składa się z następujących etapów - w pierwszej kolejności spin doctor rozpoznaje otoczenie komunikacyjne, sprawdza jakimi tematami interesują się w danej chwili media oraz opinia publiczna. Następnie przygotowuje materiały na użytek mediów. Trzeci etap związany jest z organizacją i przeprowadzeniem medialnego wydarzenia bądź przesłaniem dziennikarzom przygotowanego materiału. W kolejnej fazie spin doctor czuwa, żeby przygotowane wydarzenie zamieniło się w przekaz medialny (news). Efektem tych działań powinna być dyskusja o danym wydarzeniu wśród dziennikarzy - komentatorów (tzw. pundits). W ostatniej fazie zachodzi proces ewaluacji projektu i rozpoczęcie od nowa procesu „,nakręcania” informacji i zaspokajania tym samym potrzeb mediów i dziennikarzy - komentatorów (Jabłoński, 2006, s. 236). Spin doctoring 
nie miałby racji bytu bez zjawiska „dziennikarstwa stadnego" (pack journalism), czyli bezkrytycznego podejmowania w różnych mediach tych samych, „nakręconych” wcześniej przez sztaby PR tematów. Pack journalism działa tu według następującego klucza:

a) nakręcanie informacji rozpoczynają dziennikarscy „eksperci”, publicznie spekulujący na temat przewidywanego rozwoju sytuacji. Ich zachowanie jest wyraźnym sygnałem dla specjalistów w dziedzinie politycznego public relations odnośnie zapotrzebowania wśród pundits na określone tematy;

b) specjaliści PR pracujący dla polityków dostarczają liczącym się dziennikarzom przygotowane przez siebie materiały;

c) najbardziej znaczący dziennikarze prezentują te informacje w swoich mediach, a mniej znani żurnaliści, dla których „gwiazdy dziennikarstwa” stanowią punkt odniesienia, przekazują podobne tematycznie informacje z niewielkim opóźnieniem. Tym sposobem news dłużej pojawia się w świadomości społecznej;

d) dziennikarscy „eksperci” publicznie przewidują kolejne wydarzenia, na które reagują spin doktorzy, przygotowujący nowe materiały i proces zaczyna się od początku (ibidem, s. 237).

Współczesna komunikacja pomiędzy obywatelami a elitami władzy odbywa się za pomocą mediów. Środki masowego przekazu wysyłając informacje o charakterze politycznym zwykle opatrująje komentarzem, podpowiadają interpretację. Nie muszą czynić tego wprost, mogą stosować bardziej wyrafinowane metody, jak choćby umieszczanie przekazu politycznego w odpowiednim kontekście (Pawełczyk, Piontek, 1999, s. 53).

Wolność mass mediów (czyli niezależność od cenzury władzy) wiąże się z wolnością wypowiedzi, które traktowane są jako podstawowy filar demokracji. To właśnie W zeszłym stuleciu środkom masowego przekazu zaczęto przypisywać rolę czwartej władzy. Zdaniem B. Dobek-Ostrowskiej media nie dysponują realną władzą, taką jak polityczna czy ekonomiczna. Posiadają natomiast czwarty typ władzy, który można określić jako władzę symboliczną. Badaczka nawiązując do A. Giddensa uważa, że siła mediów sprowadza się „,do prestiżu, respektu, do symbolicznego kapitału. Dzięki nim mogą wpływać na umysły odbiorców, na ich postawy i zachowania, preferencje, oczekiwania, gusty, życzenia i zainteresowania [...] Zwolennicy pojmowania mediów jako czwartej władzy przypisują im rolę niezależnego podmiotu w systemie politycznym, akcentując funkcję informacyjną, opiniotwórczą, krytyczną i kontrolną" (Dobek-Ostrowska, 2004, s. 142).

Siła mediów opiera się na ich wiarygodności. Jak zauważa P. Żuk w czasach realnego socjalizmu oficjalne media budziły nieufność. Po 1989 roku społeczeństwo polskie uznało media za wolne, niezależne, dzięki temu łatwiej przyjmuje informacje przekazywane przez środki masowego przekazu. Społeczeństwo uwierzyło, że jedynie rząd oraz agendy instytucji państwa mogą wprowadzać cenzurę, ograniczać i nadzorować wolność mediów. Dzięki takiemu przeświadczeniu media łatwiej i skuteczniej narzucają społeczeństwu wizje oraz poglądy klasy panującej, ograniczając tym samym pluralizm i narzucają tematy, które uznawane są powszechnie za słuszne. Media dokonują tego w taki sposób, że niewiele osób uznaje te działania za manipulację (Żuk, 2006, s. 40-41).

Współczesne media zaczęły odchodzić stopniowo od swojej głównej roli, czyli informowania i służenia opinii publicznej na rzecz kształtowania rzeczywistości społecznej poprzez wpływanie na decyzje polityków oraz obywateli (m.in. niektórzy dziennikarze 
zaczęli angażować się czynnie w kampanie wyborcze, popierając konkretne partie polityczne). Można odnieść wrażenie, że część dziennikarzy sprzyjając poszczególnym politykom utraciła swoją najcenniejszą cechę, czyli obiektywizm. Pewna grupa dziennikarzy w poszukiwaniu sensacji podporządkowuje się politykom, jest na ich usługach - ,media stały się w tym przypadku elementem gry o władzę. Zarówno komercyjne, jak i publiczne środki przekazu, a raczej ich właściciele lub zarządcy, w trosce o własny interes, zaczęli zmieniać konfigurację polityczną, szukając poparcia $\mathrm{u}$ - jak wskazują sondaże - przyszłej władzy" (Brachfogel, 2005, s. 27).

Mimo występowania w środkach masowego przekazu powyższych elementów manipulacji nie możemy zapominać o funkcji informacyjnej. Według P. Pawełczyka i D. Piontek przyznanie mediom funkcji kanałów transmitujących przekazy polityczne (audycje wyborcze, apele, oświadczenia polityków, ale także komentarz dziennikarski), odbija również sytuowanie ich funkcji informacyjnej na czele wszystkich znaczących typologii (Pawełczyk, Piontek, 1999, s. 48).

Nie można zakładać a priori złej woli mediów, obraz świata przedstawiany w środkach masowego przekazu nie jest jego wierną kopią, ulega natomiast przeobrażeniom wskutek interpretacji i selekcji materiału.

Należałoby zadać pytanie, dlaczego przedstawiciele mass mediów ulegają ,czarowi” polityków? Można wysnuć wniosek, że powstaje specyficzna symbioza pomiędzy dziennikarzami a politykami - jak podkreśla B. Dobek-Ostrowska, media upowszechniając wyniki badań opinii publicznej, często uważają siebie za jej reprezentanta. Dodatkowo media thumaczą i oceniają sytuację polityczną, krytykują lub wychwalają indywidualnych albo zbiorowych aktorów politycznych. $Z$ tego powodu część badaczy proponuje, aby w analizie komunikowania politycznego wyróżnić dwa typy aktorów: politycy (nadawcy polityczni) oraz profesjonalny personel mediów (nadawcy medialni). Pierwsi reprezentowaliby instytucje polityczne, drudzy - organizacje medialne (Dobek-Ostrowska, 2004, s. 69).

Politycy występujący w mediach mają darmową reklamę, są zapamiętywani przez obywateli, a dziennikarze otrzymują kolejne sensacyjne informacje, dzięki którym wzrasta oglądalność albo sprzedaż gazet. Jednocześnie próbują pozyskać przychylność środków masowego przekazu wywyższając je do rangi czwartej władzy. Taka nobilitacja może być jedną z przyczyn, dla której część przedstawicieli mediów zaczyna popierać konkretną frakcję polityczną. W zamian mass media uwiarygodniają „swoich” polityków (pokazują ich z jak najlepszej strony, a przeciwną frakcję niszczą przy pomocy niedomówień, niesprawdzonych informacji). Taką sytuację można zaobserwować nie tylko w krajach demokratycznych, ale także w innych systemach politycznych, w których mass media pełnią rolę nie tylko informacyjna, ale także kreacyjną. „O dostęp do mediów toczy się ciągła walka polityczna, ponieważ posiadają one zdolność rytualizacji poprzez nadawanie określonym znakom znaczenia politycznego" (Pawełczyk, Piontek, 1999, s. 25).

Dzięki tematom sensacyjnym rosną przychody ze sprzedaży informacji masowym odbiorcom. Właściciele mediów oczekują, że w krótkim czasie ich informacje „newsowe" dotrą do jak najszerszego grona obywateli, a reklamodawcy nie będą szczędzić pieniędzy na czas antenowy lub rubrykę reklamową w gazecie. Ekonomiczne uzależnienie mediów m.in. od reklamodawców powoduje, że pokazuje się zachowania i wypowiedzi aspołeczne polityków, głównie w celu zwiększenia „oglądalności”. 
Według P. Bourdieu, dziennikarze stosują selekcję zarówno w doborze tematów, jak i zapraszanych do studia gości. Osoby zaproszone jak i sami dziennikarze muszą wypowiadać się szybko, dostosować się do presji czasu. Dogłębna analiza tematu nie jest ważna, liczy się przede wszystkim sensacja. W dodatku telewizja wykorzystuje dramaturgię w podwójnym sensie tego słowa: reżyseruje wydarzenie (inscenizuje je w obrazach) oraz wyolbrzymia jego znaczenie (nadaje mu charakter dramatu i tragedii) (Bourdieu, 2009, s. 45).

Termin ,wideopolityka” stworzył G. Sartori, który rozumie to pojęcie jako wpływ telewizji na procesy zachodzące w polityce. „Telewizja w znacznym stopniu warunkuje proces wyborczy, zarówno w kwestii doboru kandydatów, stylu ich walki w zmaganiach o mandat, jak i w tym, kto na końcu zwycięża. Ponadto telewizja warunkuje działania rządu, jego wybory i decyzje - co może i czego nie może zrobić oraz jak konkretnie postanowi sprawy rozwiązać" (Sartori, 2007, s. 38). Politycy dostosowują się do tematów narzucanych przez środki masowego przekazu. Globalne media poświęcają wiele uwagi takim zagadnieniom jak ochrona środowiska, odnawialne źródła energii, nowoczesne technologie. Liderzy polityczni w swoich wystąpieniach zaczynają również przywiązywać do tego dużą wagę (Wilkos, 2010, s. 72). Do głównych zadań dziennikarzy relacjonujących kampanie wyborcze należy: przybliżenie sylwetek kandydatów; ustalenie hierarchii problemów i priorytetów; informowanie o przebiegu kampanii; analizowanie strategii; taktyki i planu kampanii; przypominanie o wadze i znaczeniu wyborów; wyrażanie nastrojów społecznych (Mrozowski, 2001, s. 141-142).

Według J. Habermasa, opanowana przez masowe media sfera publiczna przejęła funkcję reklamy. Partie wykorzystują techniki podobne do reklamy handlowej w celu wpływania na decyzje wyborców. „Agitatorzy i propagandziści w dawnym stylu ustępują miejsca politycznie neutralnym fachowcom od reklamy, zatrudnianym, by apolitycznie sprzedawać politykę" (Habermas, 2007, s. 391). Współczesne demokracje w krajach wysoko rozwiniętych tworzą społeczeństwo informacyjne, w których informacja staje się podstawowym zasobem. Społeczeństwa w dobie rozwoju nowoczesnych technik informacyjnych sprawują większą kontrolę nad władzą, niż miało to miejsce w przeszłości. Zdaniem B. Dobek-Ostrowskiej wybory nie są dzisiaj jedynym źródłem legitymizacji władzy politycznej, zostały one poszerzone o sprawność porozumiewania się aparatu władzy z obywatelami, a także o umiejętności sięgania po narzędzia audiowizualne i wykorzystania ich w codziennej praktyce politycznej. Przeobrażenia sfery publicznej, jakie dokonują się pod wpływem mediów, głównie telewizji i Internetu, dają możliwość ciągłej legitymizacji bądź delegitymizacji politycznej, która w erze przed-telewizyjnej ograniczała się jedynie do wyborów (Dobek-Ostrowska, 2007, s. 276).

Jak podkreśla K. Krzysztofek, przeciętny Polak ponad 90\% informacji czerpie z telewizji, jednak już blisko 40\% Polaków ma stały lub okazjonalny dostęp do Internetu. Polityczna rola Internetu jest jeszcze słaba w porównaniu z innymi krajami europejskimi, jednak widać już działania w sieci mające na celu samoorganizację internautów wokół politycznych celów (Krzysztofek, 2008, s. 26). Zainteresowanie specjalistów od marketingu politycznego możliwościami wykorzystania Internetu w komunikacji wyborczej wynika przede wszystkim z szeregu zmian cywilizacyjnych. Szczególne znaczenie mają tu: 1) pogłębiający się spadek uczestnictwa w wyborach; 2) pojawienie się nowego, odmiennego od dotychczasowych, pokolenia młodych wyborców. Są to osoby urodzone po 
1980 roku, określane mianem Generacji Y lub Millenium Kids, wychowane na przekazie telewizyjnym oraz posługujące się sprawnie Internetem, dzięki temu są świadomi świata, w którym żyją; 3) upowszechnienie dostępu do Internetu; 4) wpływowe lobby firm zajmujących się wytwarzaniem i wdrażaniem różnego rodzaju technologii komputerowych oraz 5) rozrastający się i przynoszący olbrzymie dochody internetowy rynek usług konsumpcyjnych (Cwalina, 2001, s. 408-409).

W związku z tym należy zwrócić uwagę na aktualnie obserwowane zjawisko budowania przez informację tak zwanego świata „rzeczywistości wirtualnej”. Z jednej strony obywatele mogą wpływać na rządzących, z drugiej powszechny dostęp do informacji stwarza pokusę wykorzystywania informacji jako narzędzia walki o władzę i skuteczny sposób manipulowania społeczeństwem poprzez podawanie informacji (w tym również sprzecznych), zagrażających całej grupie. Taka informacja często konstruuje w umysłach ludzi iluzje, sztuczne światy, których niebezpieczeństwo polega na mieszaniu się fikcji z rzeczywistością. Można więc w umyśle człowieka konstruować pewne obrazy rzeczywistości, które określałyby nastawienia i preferencje ludzi w dziedzinie kształtowania oczekiwanych zachowań $\mathrm{w}$ tak strategicznych dla państwa problemach, jak sfera społeczna i polityczna (Falkowski, Michalak, 2009, s. 251).

W rozwijających się społeczeństwach informacyjnych wiadomość staje się podstawowym zasobem produkcyjnym. Jak zauważają A. Falkowski i M. Michalak dysponowanie informacją może stać się narzędziem walki o władzę i skutecznym sposobem kontrolowania społeczeństwa. Rozpowszechnianie pewnych informacji wytwarza w ludzkich umysłach iluzje, sztuczne światy, których niebezpieczeństwo polega na mieszaniu się fikcji z rzeczywistością (ibidem, s. 251). Internet (w tym blogi) mogą stać się narzędziem walki politycznej, której celem będzie m.in. zdyskredytowanie przeciwników, prowadzenie marketingu szeptanego, wykorzystywanie propagandy w celu manipulowania wiedzą i nastrojami społecznymi. W społeczeństwie informacyjnym Internet umożliwia bezpośrednią (z pominięciem dziennikarzy) komunikację z wyborcami, na której zależy przede wszystkim partiom politycznym - „W państwach demokratycznych celem jest przede wszystkim względne uniezależnienie się od innych mediów, a mówiąc ściślej od dziennikarzy, którzy często rozpowszechniają własny obraz partii, polityków i ich działań, jakże odmienny od tego, jaki dany podmiot polityczny chciałby przekazać społeczeństwu" (Walczak-Duraj, 2006, s. 239).

Jak podkreśla D. Walczak-Duraj, Internet daje partiom politycznym możliwość upowszechniania informacji oraz wszelkich sprostowań. Fałszywe, kłamliwe, oczerniające informacje można zdementować, co pozwala choćby częściowo uspokoić opinię publiczną, a zwłaszcza ten segment elektoratu, który cechuje się wysokim poziomem identyfikacji z danym ugrupowaniem politycznym (ibidem, s. 240).

Politycy wykorzystują portale społecznościowe (takie jak Twitter czy Facebook) oraz blogi do kreowania swojego wizerunku. Czynią to, ponieważ sami mogą decydować o zamieszczanych treściach i komunikując się z opinią publiczną nie są zależni od tradycyjnych mediów, które czasami zniekształcały obraz polityka i prezentowane przez niego treści; przykładowo były przewodniczący SLD Grzegorz Napieralski ,prowadzi bloga, posiada konta w 7 serwisach społecznościowych, używa komunikatorów i opublikował na swoim koncie w YouTube znaczną liczbę filmików. Blog aktualizowany jest co kilka dni, czasem kilka razy w ciagu dnia. Grzegorz Napieralski ma konta na YouTube, Face- 
booku, MySpace, Naszej Klasie, Flakerze, Twitterze, Yam.pl, Blipie. Na stronie są też ikonki umożliwiające kontakt przez Skype i Gadu-Gadu. Na YouTube ma 32 filmy, mimo iż zostało utworzone w kwietniu 2010 roku. Na Naszej Klasie ma natomiast 18 tys. znajomych. Jest jednym z najaktywniejszych polityków w sieci” (Stojkow, 2011, s. 178-179).

Środki masowego przekazu, zarówno te tradycyjne (gazety, radio, telewizja) jak i Internet wywierają ogromny wpływ na marketing polityczny i wyborczy. Politycy korzystający z usług ekspertów ds. wizerunku zdają sobie sprawę, że wygranie wyborów oraz utrzymanie władzy zależy nie tylko od wiedzy merytorycznej polityka, ale również od wykreowanego w mediach wizerunku, który odgrywa decydującą rolę w oczach opinii publicznej, oddającej swój głos w sondażach czy przy urnie wyborczej.

\section{Podsumowanie}

W oparciu o literaturę przedmiotu zaprezentowałem zależności zachodzące pomiędzy sferą polityki a środkami masowego przekazu. Jestem świadomy, że pokazałem jedynie wybrane aspekty z omawianej dziedziny i nie przedstawiłem wszystkich aspektów oraz podejść teoretycznych do omawianej problematyki. Celem tego artykułu było jedynie zasygnalizowanie, że partie oprócz tożsamości ideologicznej posiadają również coraz ważniejszą tożsamość wizerunkową, która wpływa na przebieg i wyniki wyborów parlamentarnych. Opisane w tym artykule mechanizmy rządzące środkami masowego przekazu oraz marketingiem politycznym prowadzą do sytuacji, w której wyborca staje się obserwatorem wyreżyserowanej (zwłaszcza przez te dwa podmioty) rzeczywistości politycznej. W dniu wyborów obywatele często oddają swój głos na wykreowany wizerunek polityka, który spełniał ich oczekiwania.

Z drugiej strony formy dotarcia do wyborców są coraz trudniejsze, ponieważ prowadzenie tradycyjnych kampanii wyborczych wiąże się z coraz większymi wydatkami - średnio 200 tys. zł kosztowało partie zdobycie jednego mandatu poselskiego i senatorskiego w wyborach z 2007 r. PO, PiS, SLD i PSL wydały wówczas po niemal $30 \mathrm{mln}$ zł na swoje kampanie. W sumie te partie wydały prawie $112 \mathrm{mln}$ zł - najwięcej PO - $29 \mathrm{mln}$ 427 tys. zł, najmniej Lewica i Demokraci - 26 mln 114 tys. zł $\mathfrak{l}^{3}$. W 2011 roku najwięcej na kampanię wyborczą wydało Prawo i Sprawiedliwość (30 mln 119 tys. zł). Na kolejnych miejscach znalazły się: PO - 29 mln 274 tys. zł; SLD - 24 mln 163 tys. zł; PSL - 12 mln 699 tys. zł; Ruch Palikota - 1 mln 748 tys. zł $^{4}$.

\footnotetext{
${ }^{3}$ Wyniki na podstawie komunikatu Państwowej Komisji Wyborczej z dnia 19 maja 2008 r. http://pkw.gov.pl/wybory-do-sejmu-rp-i-do-senatu-rp-2007/komunikat-panstwowej-komisji-wyborczej-z-dnia-19-maja-2008-r-o-przyjetych-i-odrzuconych-sprawozdaniach-wyborczych-komitetow-wyborczych-uczestniczacych-w-wyborach-do-sejmu-rzeczypospolitej-polskiej-i-do-senatu-rzeczypospolitej-polskiej-przeprowadzonyc.html.

${ }^{4}$ Wyniki na podstawie komunikatu Państwowej Komisji Wyborczej z dnia 16 lipca 2012 r. http://pkw.gov.pl/wybory-do-sejmu-rp-i-do-senatu-rp-2011/komunikat-panstwowej-komisji-wyborczej-z-dnia-16-lipca-2012r.html, 14.12.2013.
} 
W ciagu czterech lat (od 2007 do 2011 roku) wzrosły koszty prowadzenia kampanii wyborczej - wydatki rzędu 200 tys. zł pozwalały opłacić w 2011 roku dwudniową reklamę na portalu Onet.pl, którą mogło obejrzeć w ciagu dnia 3,5 mln użytkowników. Trzydziestosekundowa reklama telewizyjna w najlepszym czasie antenowym to wydatek rzędu 60-80 tys. zł, nieco tańsze były reklamy radiowe (15-20 tys. za 30 sekund). Wynajęcie billboardu w zależności od formatu to koszt miesięczny od 600-800 zł netto za $12 \mathrm{~m}^{2}$, do $2000 \mathrm{zł}$ netto/miesiąc za $18 \mathrm{~m}^{2}$. Wynajęcie siatki wielkoformatowej na całej ścianie budynku (gigabillboard) to wydatek rzędu od kilkunastu do powyżej 100 tys. zł netto w centrum Warszawy. 20 tys. złotych pozwala na rozdanie 100 tys. ulotek. Najtańszymi formami dotarcia do wyborcy były plakaty na przystanku autobusowym (tzw. Citylighty), których miesięczny koszt to $600-800$ zł netto oraz reklama obwożona po mieście na przyczepie samochodowej (koszt 400-500 zł za dzień) (Stróżyk, Włoczyk, 4.08.2011, s. A3).

Wzrost kosztów prowadzenia kampanii wyborczej zmusza niektórych kandydatów do odwiedzania wyborców w ich domach oraz wykorzystywania zaangażowania i zapału wolontariuszy, którzy mogliby przekonywać do oddania głosu na konkretnego kandydata. Rozwój Internetu umożliwia jednocześnie prowadzenie kampanii na blogach, forach oraz na portalach społecznościowych. Dzięki temu można również ograniczyć wydatki, natomiast słabością kampanii prowadzonej w sieci jest zawężenie jej do wyborców korzystających z dobrodziejstw nowoczesnych technologii.

Jak pokazały przemiany zachodzace $\mathrm{w}$ sposobach prowadzenia kampanii wyborczych, tożsamość wizerunkowa zyskuje coraz większą popularność zarówno za sprawą tabloidyzacji mediów, czyli poszukiwaniu sensacji, ale również za sprawą rosnącej roli marketingu we współczesnej polityce. Rosnące znaczenie mediów m.in. w naszym kraju skłoniło wielu polityków do podporządkowania się regułom dyktowanym przez środki masowego przekazu. Fetyszyzacja wizerunku doprowadza do sytuacji, w której tożsamość ideologiczna traci na znaczeniu. Optymalna sytuacja polegałaby na równomiernym rozłożeniu akcentów wizerunkowych i ideologicznych.

Negatywne oceny opinii publicznej na temat polityków, wskazują, że eksponowanie wyłącznie tożsamości wizerunkowej w dłuższej perspektywie czasowej może nie gwarantować sukcesu wyborczego. Jak pokazują badania CBOS-u Polacy od lat są niezadowoleni z prac posłów i senatorów - przykładowo w czerwcu 2011 roku $65 \%$ badanych negatywnie oceniało funkcjonowanie Sejmu, a prawie połowa ankietowanych (47\%) źle oceniła prace Senatu. Najbardziej negatywne oceny posłom wystawiają zwolennicy SLD i PiS (po 80\%) i prawie połowa sympatyków PO (48\%) (Feliksiak, 2011, s. 1-3).

Politycy, zwłaszcza przed wyborami bacznie obserwują słupki poparcia społecznego, starają się dostosować do oczekiwań swojego elektoratu. Kreowany wizerunek nie jest jednak w stanie zmienić negatywnych opinii o pracach posłów i senatorów. $Z$ badań przeprowadzonych przez CBOS w 2009 roku na temat prestiżu zawodów wynika, że zawody i funkcje związane ze sprawowaniem władzy i polityką zajmują odległe miejsca na skali prestiżu zawodów. Na 33 zawody ostatnie dwa miejsca należały do posła i działacza partii politycznej. Najwięcej ocen świadczących o niskim statusie wykonywanej profesji uzyskał działacz partii politycznej (40\% deklaracji małego poważania) oraz poseł na Sejm (36\%) (Feliksiak, 2009, s. 2). Dla porównania w 1999 roku w badaniu zaprezentowano 26 zawodów, poseł uplasował się na 17 miejscu, prawie co piąty (21\%) ankietowa- 
ny deklarował niskie poważanie dla funkcji posła, z drugiej strony $42 \%$ badanych uznało tę funkcję za bardzo prestiżową. Działacz partii politycznej znalazł się na ostatnim miejscu. Jak widać, na przestrzeni lat nie zmieniła się sytuacja działaczy politycznych, którzy oceniani są najgorzej, pogorszyła się natomiast ocena pracy posłów - w 1999 roku wyprzedzali oni w rankingu m.in. starostów, księży, tokarzy, rolników czy maklerów giełdowych (Falkowska, 1999, s. 2). W 2009 roku znaleźli się natomiast na przedostatnim miejscu.

\section{Bibliografia}

Blumentahl S. (1982), The Permanent Campaign, New York.

Bourdieu P. (2009), O telewizji. Panowanie dziennikarstwa, Wydawnictwo PWN, Warszawa.

Brachfogel M. (2005), Mass media-narzędzie czy podmiot władzy?, w: Wspótczesne oblicza mediów, red. J. Marszałek-Kawa, Wydawnictwo Adam Marszałek, Torun.

Bylok F. (2011), Konsumpcja a polityka. Manipulacja i suwerenność w konsumpcji i polityce, w: Aksjologiczny i pragmatyczny wymiar wspótczesnej polityki, red. D. Walczak-Duraj, Wydawnictwo Uniwersytetu Łódzkiego, Łódź.

Cichosz M. (2004), Wizerunek lidera politycznego, w: Marketing polityczny. W poszukiwaniu strategii wyborczego sukcesu, red. M. Jeziński, Wydawnictwo Dom Wydawniczy Duet, Toruń.

Cwalina W. (2001), Internet: nowy multi - kanat marketingu politycznego, w: Internet - fenomen społeczeństwa informacyjnego, red. T. Zasępa, R. Chmura, Wydawnictwo Edycja Świętego Pawła, Częstochowa.

Cwalina W., Falkowski A. (2006), Marketing polityczny perspektywa psychologiczna, Wydawnictwo GWP, Gdańsk.

Dobek-Ostrowska B. (2004), Media masowe i aktorzy polityczni w świetle studiów nad komunikowaniem politycznym, Wydawnictwo Uniwersytetu Wrocławskiego, Wrocław.

Dobek-Ostrowska B. (2007), Komunikowanie polityczne i publiczne, Wyd. PWN, Warszawa.

Falkowska M., Prestiż zawodów, marzec 1999, www.cbos.pl.

Feliksiak M., Oceny działalności parlamentu i prezydenta, czerwiec 2011, www.cbos.pl.

Feliksiak M., Prestiż zawodów, styczeń 2009, www.cbos.pl.

Falkowski A., Michalak M. (2009), Doświadczenie i opinia w ksztaltowaniu wizerunku polityków, w: Polityka i politycy. Diagnozy - oceny - doświadczenia, red. J. Miluska, Wydawnictwo Naukowe UAM, Poznań.

Garlicki J. (2010), Komunikowanie polityczne - od kampanii wyborczej do kampanii permanentnej, „Studia Politologiczne”, nr 16.

Gunning J. P. (2001), Zrozumieć demokrację. Wprowadzenie do teorii wyboru publicznego, Wydawnictwo WSBFiZ, Warszawa.

Habermas J. (2007), Strukturalne przeobrażenia sfery publicznej, Wydawnictwo PWN, Warszawa.

Jabłoński W. (2006), Polityczne public relations a kreowanie informacji. Analiza krytyczna, w: Public relations. Znaczenie spoleczne i kierunki rozwoju, red. J. Olędzki, D. Tworzydło, Wydawnictwo PWN, Warszawa.

Jeziński M. (2005), Wizerunek polityczny jako element strategii wyborczej, w: Kampania wyborcza: marketingowe aspekty komunikowania politycznego, red. B. Dobek-Ostrowska, Wydawnictwo Uniwersytetu Wrocławskiego, Wrocław. 
Jeziński M. (2007), Elity, marketing polityczny, wybory. Uwagi na marginesie wyborów prezydenckich i parlamentarnych, „Przegląd Socjologiczny”, t. LVI/1.

Karwat M. (2008), Ucieczka przed tożsamościq. Antynomie i paradoksy identyfikacji polskich polityków i partii, w: Dylematy polskiej transformacji, red. J. Błuszkowski, Wydawnictwo Dom Wydawniczy Elipsa, Warszawa.

Karwat M. (2009), Akredytacja w życiu społecznym i politycznym, Wydawnictwo Oficyna Wydawnicza ASPRA-JR, Warszawa.

Krzysztofek K. (2008), Mediatyzacja polityki - polityzacja mediów, w: Co łaczy, co dzieli Polaków, czyli społeczeństwo informacyjne $w$ działaniu, red. L. H. Haber, S. Jędrzejewski, Wydawnictwo KUL, Lublin.

Łaska-Formejster A. (2002), Efektywność zróżnicowanych narzędzi marketingu wyborczego, w: Marketing polityczny a postawy $i$ zachowania wyborcze społeczeństwa polskiego, red. D. Walczak-Duraj, Wydawnictwo Uniwersytetu Łódzkiego, Łódź-Płock.

Matuszak G. (2010), O moralności polityków, w: Problemy współczesnej demokracji i moralności, red. J. Kopka, G. Matuszak, Wydawnictwo Uniwersytetu Łódzkiego, Łódź.

Mazur M. (2009), Tendencje i cechy procesu profesjonalizacji kampanii wyborczych, w: Uczestnictwo w wyborach i kampaniach wyborczych po 1989 roku, red. J. Fras, Wydawnictwo Uniwersytetu Wrocławskiego, Wrocław.

Mrozowski M. (2001), Media masowe: władza, rozrywka, biznes, Wydawnictwo Oficyna Wydawnicza ASPRA-JR, Warszawa.

Olędzki J. (2006), Public Relations w komunikacji społecznej, w: Public relations. Znaczenie społeczne $i$ kierunki rozwoju, red. J. Olędzki, D. Tworzydło, Wydawnictwo PWN, Warszawa.

Pawełczyk P., Piontek D. (1999), Socjotechnika w komunikowaniu politycznym, Wydawnictwo Naukowe Instytutu Nauk Politycznych i Dziennikarstwa UAM, Poznań.

Pawełczyk P. (2005), Marketing polityczny w dyktaturze mas, w: Problemy współczesnej demokracji w ujęciu socjotechnicznym, red. P. Pawełczyk, Wydawnictwo Naukowe Instytutu Nauk Politycznych i Dziennikarstwa UAM, Poznań.

Przybylski H. (2004), Politologia, Wydawnictwo Śląsk, Katowice-Warszawa.

Reykowski J. (2005), Psychologia polityczna, w: Psychologia. Podręcznik akademicki, t. III, red. J. Strelau, Wydawnictwo GWP, Gdańsk 2005.

Sartori G. (2007), Homo videns. Telewizja i postmyślenie, Wydawnictwo Uniwersytetu Warszawskiego, Warszawa.

Stojkow M. (2011), Polityka na Facebooku, czyli przemiany komunikacji politycznej, w: Aksjologiczny i pragmatyczny wymiar współczesnej polityki, red. D. Walczak-Duraj, Wydawnictwo Uniwersytetu Łódzkiego, Łódź.

Stróżyk J., Włoczyk P. (2011), Partie wydadza miliony, „Rzeczpospolita” z dnia 4.08.2011 r.

Sztumski J. (2002), Skuteczność komunikowania marketingowego w polityce, w: Marketing polityczny a postawy i zachowania wyborcze społeczeństwa polskiego, red. D. Walczak-Duraj, Wydawnictwo Uniwersytetu Łódzkiego, Łódź-Płock.

Ulicka G. (2010), Marketing polityczny a treści i postrzeganie polityki, „Studia Politologiczne”, nr 16.

Walczak-Duraj D. (2006), Wykorzystanie Internetu w komunikacji politycznej, w: Społeczeństwo informacyjne. Aspekty funkcjonalne i dysfunkcjonalne, red. L. H. Haber, M. Niezgoda, Wydawnictwo Uniwersytetu Jagiellońskiego, Kraków.

Wilkos S. (2010), Strategia komunikacji politycznej jako odpowiednik strategii budowania marki w biznesie, „Studia Politologiczne”, nr 16.

Wiszniowski R. (2002), Wprowadzenie do teorii marketingu politycznego, w: Marketing polityczny $w$ teorii i praktyce, red. A. W. Jabłoński, L. Sobkowiak, Wydawnictwo Uniwersytetu Wrocławskiego, Wrocław. 
Żuk P. (2006), Media a kontrola społeczna w czasach „wolności rynkowej”, w: Media i władza. Demokracja, wolność przekazu i publiczna debata w warunkach globalizacji mediów, red. P. Żuk, Wydawnictwo Scholar, Warszawa.

\title{
Summary
}

\section{The significance of image identity of a political party and its candidates in an election campaign}

\begin{abstract}
In modern politics, increasing importance is attached to image identity, while the role of ideological identity is diminishing. Political parties and politicians find the flexibility of both image and ideological identities more significant than a consistent ideological identity. Politicians frequently refrain from making socially unpopular decisions for fear of losing support, while creating their image in line with the expectations of their electorate. Generating an image identity is therefore becoming a goal in its own right, and is no longer related to ideological identity. In the author's opinion, these two types of identity are not mutually exclusive, but at a time where the media seek sensation, and with a society that is only marginally interested in substantive political debate, those in power choose this type of identity, which better fulfils the needs of the mass media and their audiences. The increasing role of image is more related to general socio-political transformations, in particular to decreasing party loyalty, the changing model of a political party (where an election party is evolving into a market party) and the predominance of electronic media in the public realm.
\end{abstract}

Key words: image identity, political marketing, political party, politician's image, ideological identity 
